Artikel Penelitian

\title{
Virtual Screening Peptida Bioaktif Antihipertensi dari Hidrolisat Kasein Susu Kambing Etawa
}

\author{
Sandra Hermanto \\ Program Studi Kimia, Fakultas Sains dan Teknologi, UIN Syarif Hidayatullah, Jakarta, Indonesia
}

INFO ARTIKEL

Sejarah artikel:

Revisi 26 September

Diterima 24 Oktober 2016

Tersedia online 31 Oktober 2016

Penulis korespodensi:

Email: sandra.hermanto@gmail.com

\begin{abstract}
ABSTRAK
Screening of bioactive peptides from Etawa goat milk casein hydrolyzate as antihypertensive drugs by in silico method has been conducted. The protein used is a-S1-casein precursor [Capra hircus] NCBI Reference Sequence: NP_001272624.1, a-S2-casein precursor [C. hircus] NCBI Reference Sequence: NP_001272514.1, $\beta$-casein [C. hircus] NCBI Reference Sequence: AAA30906.1 and k-casein precursor [C. hircus] NCBI Reference Sequence: NP_001272516.1. Structural design of bioactive peptides is done through simulation of enzymatic hydrolysis using three proteolytic enzymes (trypsin, chymotrypsin and pepsin) and continued to the preparation of the $3 D$ structure of the ligand. Virtual screening for peptide fragments is done by determining the value of druglikeness and protease inhibitors. It was found that from the 104 peptide fragments obtained 10 candidate bioactive peptides for simulations of molecular docking by each of the fragments through measurement of $\Delta \mathrm{G}_{\text {binding }}$ and the interaction between the candidates of bioactive peptides with amino acid residue in the active site of ACE (Angiotensin Converting Enzyme). As a positive control used lisinopril which is an ACE commercial inhibitor. The results showed there were six candidates of bioactive peptides which had $\Delta G_{\text {binding }}$ value lower than the positive control (lisinopril). Each peptide is ARPK, QMK, HK, QK, LNP and PYP which are expected to serve as an alternative antihypertensive drug.
\end{abstract}

Keywords: bioactive peptides, Etawa goat milk, antihypertensive, molecular docking, drug likeness

Penapisan peptida bioaktif dari hidrolisat kasein susu kambing Etawa yang berpotensi sebagai obat antihipertensi berdasarkan kajian in silico telah dilakukan. Protein yang digunakan adalah a-S1-kasein prekursor [Capra hircus] NCBI Reference Sequence: NP_001272624.1, a-S2kasein prekursor [C. hircus] NCBI Reference Sequence: NP_001272514.1, $\beta$-kasein [C. hircus] NCBI Reference Sequence: AAA30906.1 dan k-kasein prekursor [C. hircus] NCBI Reference Sequence: NP_001272516.1. Perancangan struktur peptida bioaktif dilakukan melalui simulasi hidrolisis enzimatik dengan menggunakan 3 jenis enzim proteolitik (tripsin, kimotripsin dan pepsin) dan dilanjutkan dengan preparasi struktur 3D ligan hasil pemotongan secara in silico. Virtual screening terhadap fragmen peptida dilakukan melalui penentuan nilai drug likeness dan protease inhibitor. Dari 104 fragmen peptida diperoleh 10 kandidat peptida bioaktif yang dilakukan simulasi molecular docking dengan mengeksplorasi daya inhibisi fragmen melalui 
perhitungan nilai $\left(\Delta G_{\text {binding }}\right)$ dan interaksi antara kandidat peptida bioaktif dengan residu asam amino pada sisi aktif enzim ACE (Angiotensin Converting Enzyme). Sebagai kontrol positif digunakan lisinopril yang merupakan inhibitor ACE komersil. Hasil penelitian menunjukkan dari 10 kandidat peptida bioaktif terdapat 6 peptida yang diduga bersifat antihipertensi dengan nilai $\Delta G_{\text {binding }}$ yang lebih rendah dari kontrol positif (lisinopril). Keenam peptida tersebut diharapkan dapat berfungsi sebagai obat alternatif antihipertensi.

Kata kunci: Antihipertensi, Peptida bioaktif, drug likeness, molecular docking, Susu kambing Etawa

\section{Pendahuluan}

Angiotensin Converting Enzyme (ACE) adalah enzim kunci yang berperan penting dalam mengatur tekanan darah pada manusia. ACE mengkatalisis hidrolisis dekapeptida angiotensin inaktif menuju vasokonstriktor angiotensin II, suatu oktapeptida yang berperan dalam mengatur tekanan darah. Selain itu, ACE juga akan memotong bradikinin suatu vasodilator menjadi fragmen tidak aktif sehingga akan menaikan tekanan darah. Inhibisi terhadap enzim ACE mampu menurunkan level angiotensin II sehingga akan menurunkan tekanan darah (Ehlers, Fox, Strydom, \& Riordan, 1989). Beberapa obat antihipertensi sintetik telah banyak digunakan sebagai agen inhibitor ACE dalam pengobatan hipertensi. Penggunaan obat-obat antihipertensi sintetik ternyata sebagian besar mengandung risiko yang dapat menyebabkan beberapa efek samping antara lain hipotensi, penurunan fungsi ginjal, batuk kering, dan kelainan janin (Parmley, 1998). Hal ini telah mendorong para peneliti untuk mencari alternatif inhibitor ACE alami yang dampaknya relatif kecil dan tidak berisiko serta tidak menimbulkan ketergantungan.

Beberapa agen inhibitor ACE alami yang telah banyak diteliti diantaranya bersumber dari protein hewani dan protein nabati (Ariyoshi, 1993). Protein susu merupakan salah satu sumber peptida bioaktif yang dapat berfungsi sebagai antihipertensi. Peptida ini dapat diproduksi melalui hidrolisis enzimatik dengan enzim proteolitik dan atau melalui fermentasi dengan bakteri asam laktat (FitzGerald, Murray, \& Walsh, 2004; Yamamoto, Akino, \& Takano, 1994). Beberapa peptida bioaktif susu mampu menghambat aktifitas ACE secara in vitro dan in vivo (Nakamura, Yamamoto, Sakai, Okubo, Yamazaki, \& Takano, 1995; LopezFandino, Otte, \& van Camp, 2006; Maeno,
Yamamoto, \& Takano, 1996; Abubakar, Saito, Kitazawa, Kawai, \& Itoh, 1998; Pihlanto-Leppala, Koskinen, Piilola, Tupasela, \& Korhonen, 2000; Geerlings et al., 2006; Lee, Kim, Ryu, Shin, \& Lim, 2005). Beberapa fragmen peptida ini juga telah ditemukan memiliki sifat antihipertensi pada hewan dan manusia (Nakamura et al., 1995; Korhonen \& Pihlanto, 2006).

Penelitian komputasi biomolekul peptida antihipertensi sebagai inhibitor ACE melalui pendekatan in silico telah dilakukan oleh beberapa peneliti sebelumnya. Wang, Zhang, Wang, Feng, \& Shan (2011) yang telah berhasil mensintesis peptida bioaktif hasil virtual skrining protein kasein susu sapi dan Li et al. (2014) yang melakukan studi in vitro, in vivo dan in silico peptida bioaktif dari hidrolisat kacang pistachio (Pistacia vera L.). Peneliti lainnya melakukan pendekatan kuantitatif in silico untuk beberapa peptida bioaktif dari hidrolisis protein whey yang memiliki aktifitas penghambatan ACE (Vermeirssen, van der Bent, van Camp, van Amerongen, \& Verstraete, 2004; Ferranti et al., 2004).

Dalam penelitian ini telah dilakukan eksplorasi peptida bioaktif dari hidrolisat protein susu kambing Etawa dengan fokus kajian pada kasein. Pendekatan secara in silico dilakukan melalui virtual screening terhadap fragmen-fragmen peptida hasil hidrolisis enzimatik yang dilakukan melalui simulasi hidrolisis enzim protease. Tiga jenis enzim proteolitik yang digunakan untuk menghidrolisis kasein yaitu pepsin, tripsin dan kimotripsin. Dasar pemilihan ketiga jenis enzim tersebut karena pepsin, tripsin dan kimotripsin merupakan komponen enzim proteolitik yang terdapat dalam sistem pencernaan manusia sehingga diharapkan hasil hidrolisis enzimatik tersebut akan menghasilkan peptida bioaktif yang tetap memiliki aktifitas fisiologis khususnya ketika diaplikasikan secara in vivo. 


\section{Bahan dan metode}

\subsection{Bahan}

Bahan penelitian terdiri dari sekuen protein aS1, a-S2, $\beta$ dan k-kasein yang diperoleh dari situs NCBI (National Center for Biotechnology InformationL, http://www.ncbi.nih.gov. Adapun struktur 3D protein enzim ACE diperoleh dari situs Protein Data Bank (PDB) RCSB, (http://www.rcsb.org/pdb/home/home.do) dengan kode 1086 yang merupakan kompleks enzim human testicular ACE-lisinopril dengan resolusi 2.0 $\AA$ (Natesh, Schwager, Sturrock, \& Acharya, 2003).

\subsection{Instrumentasi virtual screening}

Simulasi virtual screening dilakukan dengan menggunakan seperangkat PC (Personal Computer) dengan sistem operasi Windows XP Professional version 2002 Service Pack 3. Perangkat browser yang digunakan adalah Mozilla Firefox 40.0.2. Penelitian ini menggunakan beberapa perangkat lunak (software) baik online maupun offline. Perangkat lunak yang digunakan untuk simulasi penambatan molekul (molecular docking) adalah MOE (Molecular Operating Environment / Chemical Computing Group Inc. Montreal, Canada, 2009) dan CAESA (Computer Assisted Estimation of Synthetic Accessibility). Beberapa perangkat lunak offline yang digunakan diunduh secara online. Sementara yang lainnya, langsung digunakan pada web server tersebut (online software). Perangkat lunak yang dapat diakses secara online tersaji pada Tabel 1. sekuen protein kasein susu kambing Etawa. Pencarian sekuen ini diprioritaskan pada sekuen aS1, $\alpha-S 2, \beta$ dan $\mathrm{k}$-kasein melalui pendekatan bioinformatika dengan bantuan mesin pencari pada situs NCBI. Sekuen-sekuen tersebut diunduh dan disimpan dengan Notepad dalam format FASTA (Li-Chan, 2015).

\subsection{Preparasi struktur 3D enzim}

Sebelum dilakukan simulasi docking, struktur 3D enzim ACE diunduh dari situs PDB. Struktur enzim ACE yang digunakan adalah human testicular ACE dengan kode 108a (native) dan 1086 (dalam bentuk kompleks dengan lisinopril) disiapkan dalam format .pdb. Kemudian, seluruh data strukturalnya dibuka dengan perangkat lunak MOE. Langkah selanjutnya adalah membuka data sekuens (SEQ) pada MOE dan menghapus beberapa ligan/inhibitor, dan pelarut (biasanya berupa molekul air $/ \mathrm{H}_{2} \mathrm{O}$ ) yang tidak digunakan dalam simulasi. Setelah itu, penambahan hidrogen polar dilakukan menggunakan menu protonate $3 D$ pada compute. Kemudian, muatan parsial (partial charge) ditambahkan pada menu compute dengan mode forcefield MMFF94 yang biasa digunakan untuk struktur enzim. Minimalisasi energi pada struktur enzim juga perlu dilakukan hingga ke tingkat yang paling minimum menggunakan menu energy minimize. Setelah melalui berbagai tahap preparasi tersebut, enzim disimpan dalam format .MOE dan siap digunakan untuk simulasi molecular docking (Wang et al., 2011).

Tabel 1.

Perangkat lunak untuk analisis in silico

\begin{tabular}{ll}
\multicolumn{1}{c}{ Perangkat Lunak } & \multicolumn{1}{c}{ Situs } \\
\hline ACDLabs ChemSketch 12.0 & $\underline{h t t p: / / w w w . a c d l a b s . c o m / r e s o u r c e s / f r e e w a r e / c h e m s k e t c h / ~}$ \\
Lipinski Filters & $\underline{\text { http://www.scfbio-iitd.res.in/scfbiogroup/bioinformaticsindia.html/ }}$ \\
Molinspiration & $\underline{\text { http://www.molinspiration.com }}$ \\
OpenBabel 2.2.3 & $\underline{\text { http://openbabel.sourceforge.net/) }}$ \\
Osiris Property Explorer & $\underline{\text { http://www.organic-chemistry.org/prog/peo/ }}$ \\
PyMOL & $\underline{\text { http://www.pymol.org/ }}$ \\
Peptidecutter & $\underline{\text { http://web.expasy.org/cgi-bin/peptide_cutter/peptidecutter.pl }}$ \\
\hline
\end{tabular}

\subsection{Pencarian sekuen protein kasein ( $\alpha-S 1, \alpha-S 2$, $\beta$ dan $k$-kasein)}

Fragmen peptida bioaktif diperoleh dari hidrolisis kasein dengan menggunakan enzim proteolitik (pepsin, tripsin dan kimotripsin). Hal yang pertama dilakukan adalah pencarian data
2.5. Hidrolisis in silico fragmen peptida ( $\alpha-S 1, \alpha-S 2$, $\beta$ dan k-kasein) dan perancangan struktur molekul ligan

Hidrolisis $\alpha$-S1, $\alpha$-S2, $\beta$ dan $\mathrm{k}$-kasein secara in silico dilakukan dengan menggunakan perangkat lunak proteolitic site enzymatic prediction yaitu 
Expasy Peptide Cutter, http://web.expasy.org/cgibin/peptide_cutter/peptidecutter.pl) (Gasteiger, Hoogland, Gattiker, Duvaud, Wilkins, Appel, \& Bairoch, 2005). Sekuen asam amino hasil hidrolisis enzimatik dipetakan dalam bentuk tabel untuk diolah lebih lanjut dengan menggunakan perangkat lunak ACDLabs ChemSketch 12.0. Dengan menggunakan perangkat lunak yang sama, struktur fragmen peptida bioaktif atau disebut juga ligan ini kemudian diperhalus dengan fitur clean structure dan dilakukan optimisasi dalam bentuk tiga dimensi (3D). Selanjutnya, ligan disimpan dalam format MDL (Molecular Design Limited) Molfiles. Ligan dalam format MDL Molfiles ini dikonversi ke dalam format .mol menggunakan software OpenBabel 2.2.3 atau VegaZZ agar dapat digunakan pada proses docking sebagai kandidat ligan spesifik inhibitor ACE (Asoodeh, Haghighi, Chamani, Ansari-Ogholbeyk, Mojallal-Tabatabaei, \& Lagzian, 2014).

\subsection{Preparasi ligan (inhibitor ACE)}

Kandidat inhibitor ACE atau ligan spesifik dalam format .mol dibuka dengan software MOE (Molecular Operating Environment). Ligan tersebut dibuka pada database viewer kemudian di-wash, ditentukan mode partial charge-nya, dan diminimasi energinya pada menu compute. Algoritma yang digunakan pada mode partial charge dan energy minimize pada ligan sama dengan enzim, yaitu MMFF94. Ligan telah siap menjalani proses simulasi molecular docking. Untuk semua kandidat ligan yang diperoleh dari hasil hidrolisis in silico dilakukan preparasi yang sama seperti cara di atas (Asoodeh et al., 2014).

\subsection{Simulasi docking dan analisis hasil docking}

Simulasi docking dilakukan dengan menggunakan perangkat lunak MOE. File enzim ACE dalam format moe dibuka kemudian diubah mode potential setup-nya, yaitu mode solvasi menggunakan fase gas (gas phase). Setelah sistem molekuler telah siap, struktur enzim ACE kembali diperiksa dengan mengulang rangkaian preparasi enzim awal, yaitu protonate $3 D$, partial charge, dan energy minimize. Menu dock kemudian dibuka dan file ligan dipilih. Sisi aktif enzim terlebih dahulu ditentukan menggunakan sequence editor. Mode rescoring adalah London $\mathrm{dG}$ dengan mode refinement forcefield. Banyaknya posisi ligan yang fleksibel adalah 30 posisi dengan 1 nilai interaksi terbaik. Kemudian, simulasi docking dilakukan. Hasil docking dengan MOE didapat dalam format file MOE Database .mdb. Dari 30 model yang dihasilkan diperoleh satu model terbaik berdasarkan data energi bebas ikatan $\left(\Delta G_{\text {binding }}\right)$ untuk kemudian dianalisis interaksinya (Pierri, Parisi, \& Porcelli, 2010). Interaksi antara ligan inhibitor dengan residu asam amino pada enzim dapat dilihat menggunakan menu LigX pada MOE Wang et al., 2011; Kitchen, Decornez, Furr, \& Bajorath, 2004).

\subsection{Drug screening dan analisis drug scan}

Drug screening dilakukan untuk melihat apakah inhibitor yang diusulkan telah memenuhi syarat sebagai kandidat obat berdasarkan Lipinski's Rule of Five dan sifat ADMET (Absorption, Distribution, Metabolism, Excretion, and Toxicity) dari senyawa tersebut (Roy, Paul, Mitra, \& Roy, 2009). Drug scan dilakukan dengan menggunakan perangkat lunak Lipinski Filters, Molinspiration dan Osiris Property Explorer. Drug screening dilakukan untuk melihat senyawa kandidat obat dengan nilai parameter yang terbaik diantara yang lainnya. Molinspiration dan Lipinski Filters digunakan untuk menganalisis karakter molekuler seperti $\log \mathrm{P}$, jumlah donor ikatan hidrogen, jumlah akseptor ikatan hidrogen, dan massa molekul suatu obat, sedangkan Osiris Property Explorer digunakan untuk mengkalkulasi beragam sifat yang berkaitan dengan obat, seperti toksisitas, druglikeness dan drug score (Ajmani, Jadhav, \& Kulkarni, 2008).

\section{Hasil dan pembahasan}

Pengujian aktifitas antihipertensi peptida bioaktif susu kambing Etawa dilakukan melalui pendekatan molecular docking dengan parameter pencarian (EHiTS score) yang diperoleh dari hasil penambatan peptida bioaktif dengan enzim human testicular ACE (108a). Sebelum dilakukan uji penambatan (molecular docking) antara ligan (kandidat peptida bioaktif) dengan enzim ACE disiapkan terlebih dahulu sekuen protein kasein dan dilakukan hidrolisis secara in silico.

\subsection{Penyiapan sekuen protein kasein ( $\alpha-S 1, \alpha-S 2$ $\beta$ dan k-kasein)}

Protein kasein yang digunakan dalam penelitian ini berasal dari kambing Etawa $C$. hircus yang terdiri dari $a-S 1, a-S 2, \beta$ dan $\mathrm{k}$-kasein yang diperoleh dari NCBI. Hasil pencarian sekuen menunjukkan urutan sekuen dari masing-masing 
protein. Berikut urutan protein a-S1, $\alpha-S 2, \beta$ dan $\mathrm{K}-$ kasein dari susu kambing Etawa (C. hircus) (Grosclaude, Mercier, \& Ribadeau-Dumas, 1970; Lagonigro, Pietrola, D'Andrea, Veltri, \& Pilla, 2001).

>gi|311943|emb|CAA51022.1| alpha S1

casein [Capra hircus]

MKLLILTCLVAVALARPKHP INHQGLSPEVPNENLLRFVVA PFPEVFRKENINELSKDIGSESTEDQAMEDAKQMKAGSSSS SEEIVPNSAEQKYIQKEDVPSERYLGYLEQLLKLKKYNVPQ LEIVPKSAEEQLHSMKEGNPAHQKQPMIAVNQELAYFYPQL FRQFYQLDAYPSGAWYYLPLGTQYTDAPSFSDIPNPIGSEN SGKAAMPLW

>gi|6179400|emb|CAB59920.1| alpha s2-

casein [Capra hircus]

MKFF I FTCLLAVALAKHKMEHVSSSEEP INIFQE IYKQEKN MAIHPRKEKLCTTSCEEVVRNANEEEYS IRSSSEESAEVAP EEIKITVDDKHYQKALNE INQFYQKFPQYLQYPYQGP IVLN PWDQVKRNAGPFTPTVNREQLSTSEENSKKTI DMESTEVFT KKTKLTEEEKNRLNFLKI ISQYYQKFAWPQYLKTVDQHQKA MKRWTQPKTNAIPYVRYL

>gi|4495057|emb|CAB39200.1| beta-casein [Capra hircus]

MKVLILACLVALALAREQEELNVVGETVESLSSSEESITH I NKKIEKFQSEEQQQTEDELQDKIHPFAQAQSLVYPFTGPIP NSLPQNILPLTQTPVVVPPFLQPEIMGVPKVKETMVPKHKE MPFPKYPVEPFTESQSLTLTDVEKLHLPLPLVQSWMHQPPQ PLSPTVMFPPQSVLSLSQPKVLPVPQKAVPQRDMPIQAFLL YQEPVLGPVRGPFPILV

>gi|550822302|ref|NP 001272516.1| kappacasein precursor [Cap̄ra hircus]

MMKSFFLVVTILALTLPFLGAQEQNQEQP ICCEKDERFFDD KIAKY I I QYVLSRYPSYGLNYYQQRPVALINNQFLPYPYY AKPVAVRSPAQTLQWQVLPNTVPAKSCQDQPTTLARHPHPH LSFMAI PPKKDQDKTEVPAINTIASAEPTVHSTPTTEAIVN TVDNPEASSESIASASETNTAQVTSTEV

\subsection{Preparasi struktur 3D enzim ACE}

Pencarian struktur 3D enzim human ACE diperoleh dari database RCSB-PDB (Research Collaboratory for Structural Bioinformatics-Protein Data Bank) yang diakses dari http://www.rcsb.org/pdb/ dengan kata kunci Human Angiotensin I Converting Enzyme. Hasil pencarian diperoleh struktur kristal enzim ACE dalam keadan native dengan kode DOI: $10.2210 / \mathrm{pdb} 108 \mathrm{a} / \mathrm{pdb}$ dan kompleks enzim human ACE dengan Lisinopril dengan kode DOI: 10.2210/pdb1086/pdb. Struktur 3D enzim human ACE ditunjukkan pada Gambar 1.

Enzim ACE merupakan kelas karboksipeptidase yang mengkonversi angiotensin I menjadi angiotensin II dengan melepas dipeptida pada terminal $\mathrm{C}$ dan inaktivasi bradikinin menjadi bradikinin 1-7, sebuah vasodilator. Aktifitas katalitiknya sangat dipengaruhi oleh keberadaan kofaktor $\mathrm{Zn}^{2+}$ dan ion klorida. Enzim ini memiliki nilai $\mathrm{K}_{M}=6,9 \mu \mathrm{M}$ untuk angiotensin $\mathrm{I}, \mathrm{K}_{\mathrm{M}}=2 \mu \mathrm{M}$ untuk bradikinin dan $\mathrm{K}_{\mathrm{M}}=2,51 \mathrm{mM}$ untuk Hip-HisLeu serta $\mathrm{pH}$ optimum 6,5 dalam larutan $\mathrm{NaCl} 1 \mathrm{M}$. Rentang aktifitas pH berada pada kisaran 6-9. struktur 3D enzim menunjukkan adanya rongga diisi oleh empat heliks dan satu $\beta$-strand. Tiga dari struktur heliks berisi residu asam amino yang bermuatan dan membatasi akses polipeptida yang lebih besar ke arah sisi aktif enzim. Dua ion klorida terikat untuk bagian dalam enzim yang berdekatan dengan sisi aktif enzim yang mengandung ion $\mathrm{Zn}$ (II). Sisi aktif yang mengandung $\mathrm{Zn}(\mathrm{II})$ terikat pada HEXXH + E motif (His383, His387 dan Glu411) dan satu molekul air yang berikatan koordinasi pada posisi keempat (Natesh et al., 2003).

(a)

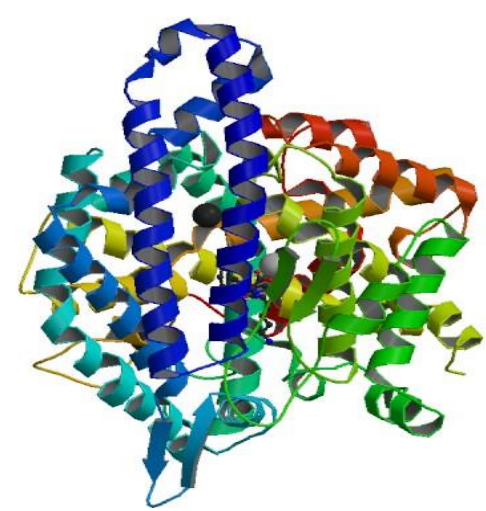

(b)

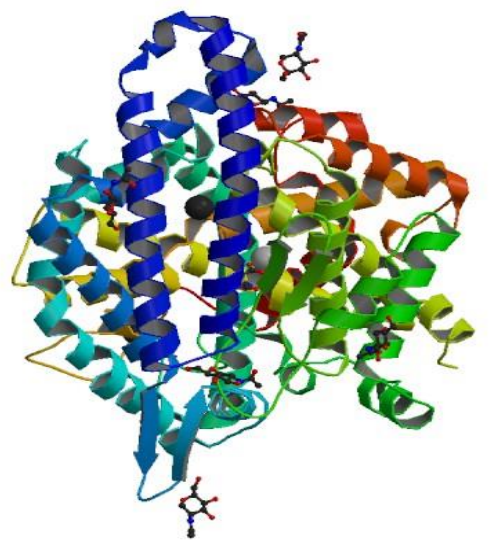

Gambar 1. Struktur 3D enzim ACE dalam 2 keadaan (a) native dan (b) kompleks enzim ACE dengan lisinopril (Natesh et al., 2003).

Terdapat empat binding subsites (S1, S2, S1' dan S2') yang berada pada sisi aktif enzim. Pusat aktif gugus karbonil antara jembatan thiol dan terminal residu prolin dilekatkan melalui dua ikatan hidrogen yang dimediasi oleh (His513, 2,69 $\AA$; His353, 2,54 A). Ikatan kompleks inhibitor-ACE ini distabilkan oleh interaksi lainnya melalui atom oksigen dari residu prolin karboksilat dengan 
Tyr520 (2,66 Å), Gln281 (3,1 A), dan Lys511 (2,73 Å) (Natesh et al., 2003).

\subsection{Hidrolisis proteolitik protein kasein ( $\alpha-S 1, \alpha-S 2$,} $\beta$ dan $k$-kasein)

Simulasi hidrolisis enzimatik dilakukan secara in silico melalui pendekatan fragmentasi proteolitik dimana digunakan 3 jenis enzim proteolitik yaitu pepsin, tripsin dan kimotripsin. Hasil hidrolisis in silico, nilai drug likeness dan protease inhibitor terangkum dalam Tabel 2, 3, 4 dan 5 (File tambahan/supplementary file).

Berdasarkan hasil hidrolisis proteolitik (pepsin, tripsin dan kimotripsin) terhadap a-S1, a-S2, $\beta$ dan k-kasein diperoleh 101 fragmen peptida yang selanjutnya dipilih berdasarkan nilai drug likeness dan protease inhibitor terbaik dengan mengunakan software Lipinski Filters, Molinspiration dan Osiris Property Explorer. Parameter yang digunakan sesuai dengan aturan Lapinski yang menyatakan bahwa suatu kandidat obat yang aktif secara oral memiliki kriteria sebagai berikut (Lipinski \& Hopkins, 2004): memiliki tidak lebih dari 5 donor ikatan hidrogen (atom nitrogen atau oksigen yang mengikat satu atau lebih ikatan dengan hidrogen), memiliki tidak lebih dari 10 akseptor ikatan hidrogen (atom nitrogen atau oksigen), massa molekuler kurang dari $500 \mathrm{Da}$ (dalton), dan memiliki koefisien partisi oktanol-air (logP) tidak lebih dari 5.

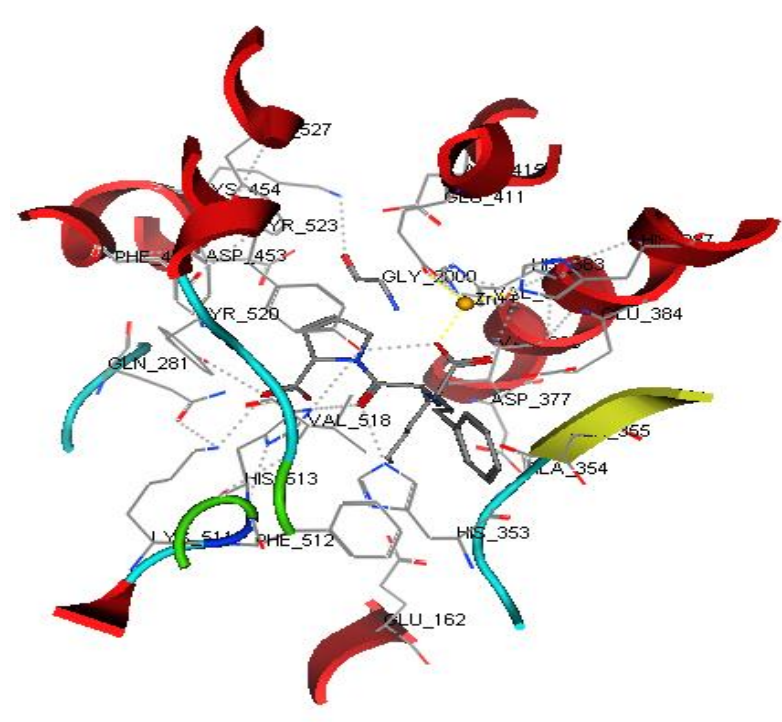

(a)
Berdasarkan hasil virtual screening terhadap 101 kandidat peptida diperoleh 10 kandidat peptida bioaktif dengan nilai druglikeness terkecil (mendekati nol) dan protease inhibitor tertinggi diantara masing-masing kandidat peptida. Selanjutnya, terhadap sepuluh kandidat peptida bioaktif hasil virtual screening dilakukan uji penambatan (molecular docking) dengan mengamati daya inhibisinya terhadap sisi aktif enzim ACE.

\subsection{Simulasi docking peptida bioaktif}

Dalam simulasi docking ini digunakan inhibitor ACE komersil yaitu lisinopril dengan nilai parameter drug-likeness 0,51 dan nilai protease inhibitor 0,91 sebagai kontrol positif. Simulasi docking enzim ACE dengan inhibitor lisinopril dilakukan pada algoritma forcefield MMFF94x dan mode solvasi gas phase, placement, rescoring, dan refinement dengan parameter yang dipilih masing-masing adalah Triangle Matcher, London dG, dan Forcefield pada daerah binding subsites (S1, S2, S1' dan S2') yang berada pada sisi aktif enzim (El Ashry el et al., 2012; Pierri et al., 2010).

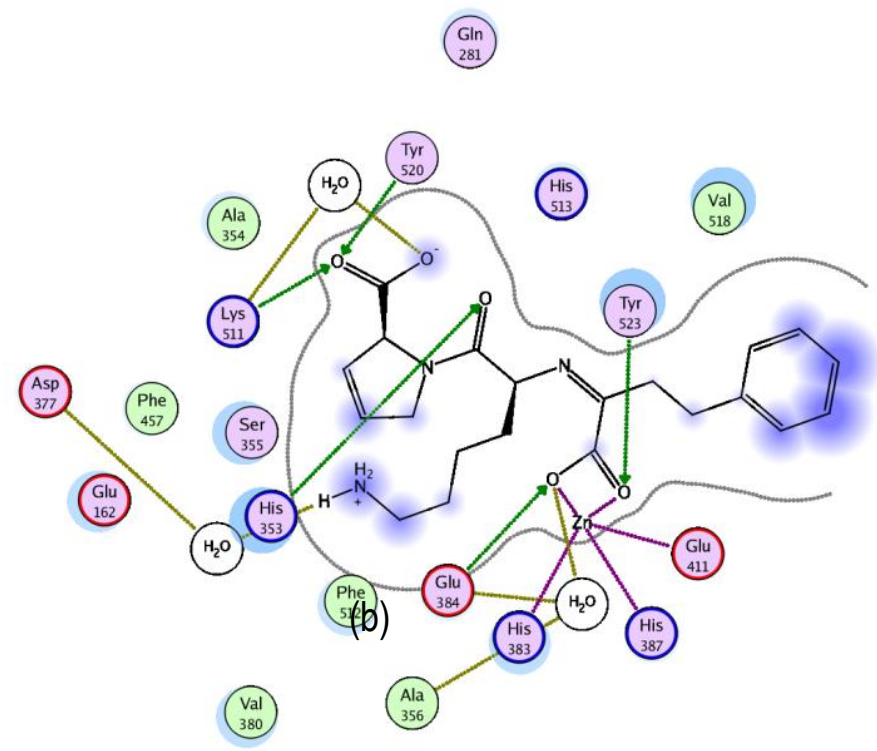

Gambar 2. (a) Pembentukan kompleks 3D lisinopril-ACE hasil simulasi docking dan (b) interaksi 2D lisinopril dengan enzim ACE (MOE 2009). 


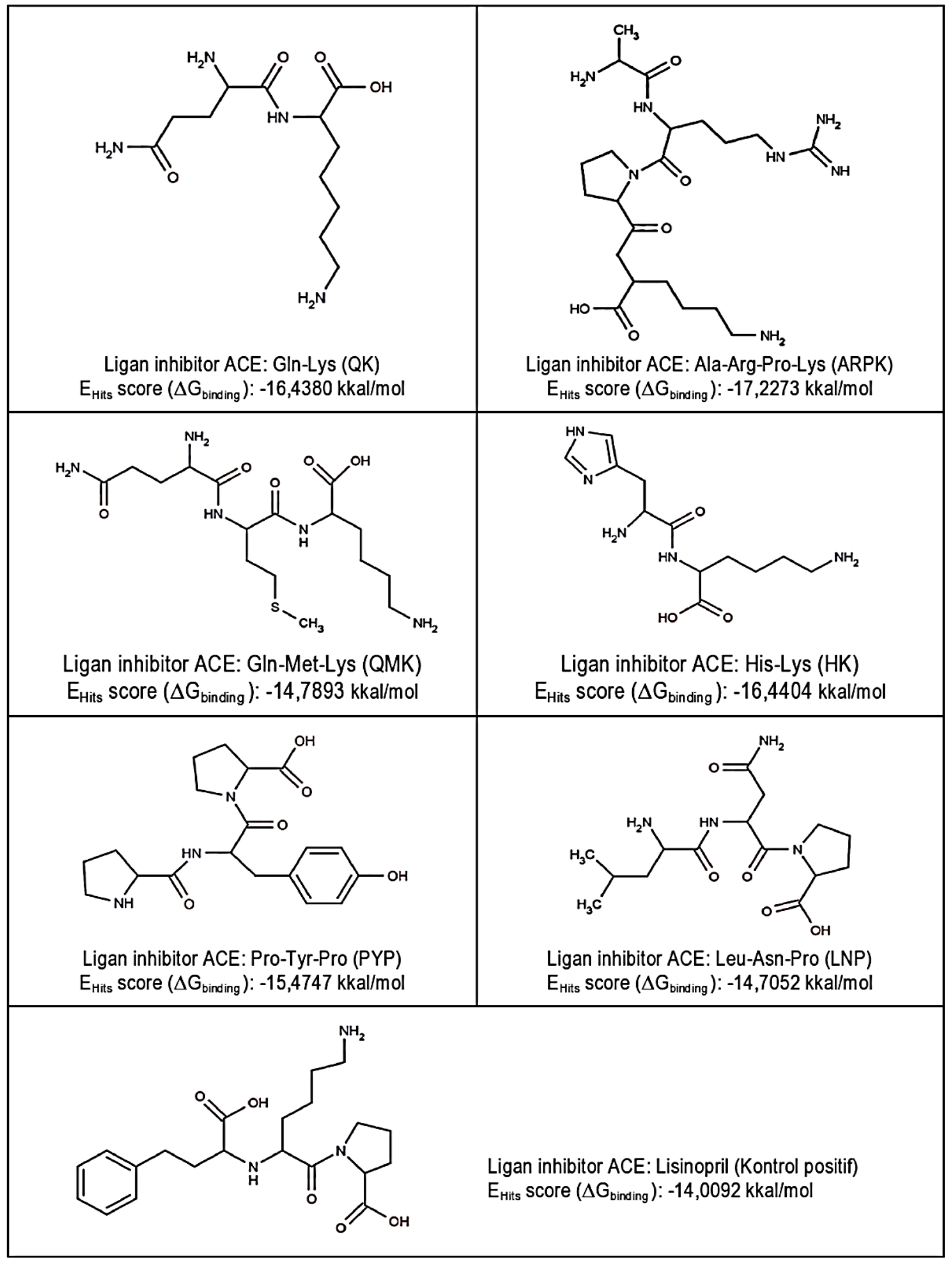

Gambar 3. Nilai $\Delta G$ hasil simulasi enam ligan potensial inhibitor ACE. 
Hasil simulasi docking menunjukkan lisinopril berikatan dengan $\mathrm{Zn}(\mathrm{II})$ pada pusat aktif melalui residu Tyr523 yang berinteraksi dengan gugus karboksil dari lisinopril dengan jarak 2,77 $\AA$ dan Glu411 (2,00 Å) (Gambar 2). Pusat aktif gugus karboksil lainnya dari lisinopril membentuk jembatan hidrogen dengan Glu384 dan Ala356 serta interaksi ikatan hidrogen antara gugus karbonil dari prolin lisinopril dengan residu His353 dengan jarak 3,11 A dan distabilkan oleh Asp377. Ikatan kompleks inhibitor-ACE ini distabilkan oleh interaksi lainnya melalui gugus karboksil dari residu prolin karboksilat dengan Tyr520 (2,56 ̊) dan Lys511 (2,93 A) (Gambar 2).

Hasil simulasi docking (Gambar 3) menunjukkan dari sepuluh kandidat peptida bioaktif terdapat 6 kandidat peptida bioaktif yakni ARPK, QMK, HK, QK, LNP, dan PYP yang menghasilkan $\Delta G_{\text {binding }}$ relatif lebih rendah dibandingkan dengan interaksi ACE-lisinopril dengan $\Delta G_{\text {binding }}-14,0092$ $\mathrm{kkal} / \mathrm{mol}$. Artinya keenam peptida tersebut memiliki aktivitas penghambatan ACE yang relatif lebih tinggi dibandingkan lisinopril sedangkan keempat peptida lainnya (PSY, PLP, PQY, dan PQL) menunjukkan aktifitas inhibisi yang relatif lebih rendah.

Berdasarkan hasil simulasi docking pada Gambar 3 terlihat bahwa interaksi ligan ARPK dengan ACE menghasilkan $\Delta G_{\text {binding }}$ terendah ($17,2273 \mathrm{kkal} / \mathrm{mol}$ ), dimana interaksi molekul ligan ini relatif lebih stabil jika dibandingkan interaksi lisinopril (kontrol positif) pada kondisi parameter docking yang sama. Hal ini menunjukkan bahwa ligan ARPK memiliki kemampuan inhibisi yang lebih baik terhadap enzim ACE dibandingkan dengan lisinopril. Interaksi kompleks 2D ligan ARPK dengan sisi aktif ACE dapat dilihat pada Gambar 4.

Interaksi yang terjadi antara ligan dengan reseptor didominasi oleh ikatan hidrogen antara residu Thr302 sebagai dengan gugus karboksil dari residu alanil dalam ligan ARPK dan interaksi asam basa antara Asp300 (sebagai donor hidrogen) dengan terminal amina dari ligan serta Asp453 (akseptor H) dan Asp453 dengan gugus samping dari residu lisin dalam ligan ARPK. Interaksi tersebut memungkinkan stabilitas energi ikatan semakin tinggi dan interaksi yang terjadi membentuk konformasi yang lebih stabil (Pierri et al., 2010).

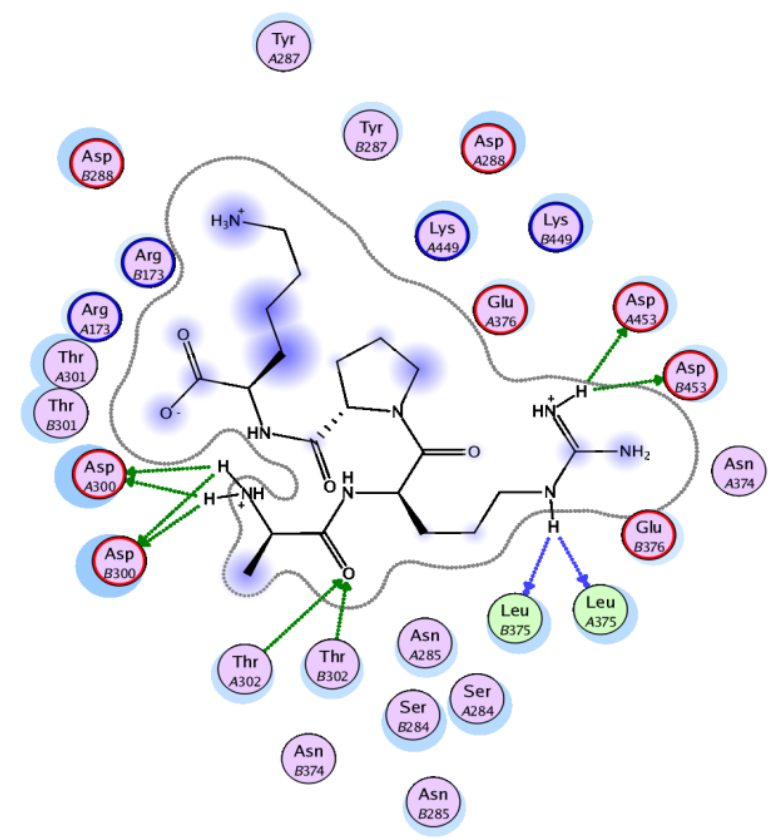

Gambar 4. Interaksi 2D ligan ARPK dengan enzim ACE (MOE 2009)

\section{Kesimpulan}

Hasil virtual screening secara in silico terhadap peptida bioaktif antihipertensi dari hidrolisat kasein susu kambing Etawa menghasilkan 6 kandidat peptida bioaktif yang memiliki aktivitas antihipertensi lebih tinggi terhadap enzim ACE jika dibandingkan dengan ligan inhibitor komersil (lisinopril). Keenam kandidat peptida bioaktif tersebut antara lain ARPK, QMK, HK, QK, LNP dan PYP. Hasil virtual screening ini diharapkan dapat dijadikan rujukan dalam sintesis peptida bioaktif yang dapat dimanfaatkan sebagai pengganti obat antihipertensi komersil.

\section{Daftar pustaka}

Abubakar, A., Saito, T., Kitazawa, H., Kawai, Y., \& Itoh, T. (1998). Structural analysis of new antihypertensive peptides derived from cheese whey protein by proteinase $\mathrm{K}$ digestion. Journal of Dairy Science, 81(2), 3131-3138. doi:10.3168/jds.S00220302(98)75878-3

Ajmani, S., Jadhav, K., \& Kulkarni, S.A. (2008). Group-based QSAR (G-QSAR)L mitigating interpretation challenges in QSAR. QSAR \& Combinatorial Science, 28, 36-51. doi:10.1002/qsar.200810063 
Ariyoshi, Y. (1993). Angiotensin-converting enzyme inhibitors derived from food proteins. Trends in Food Science \& Technology, 4(5), 139-144. doi:10.1016/09242244(93)90033-7

Asoodeh, A., Haghighi, L., Chamani, J., AnsariOgholbeyk, M.A., Mojallal-Tabatabaei, Z., \& Lagzian, M. (2014). Potential angiotensin I converting enzyme inhibitory peptides from gluten hydrolysate: biochemical characterization and molecular docking study. Journal of Cereal Science, 60(1), 92-98. doi:10.1016/j.jcs.2014.01.019

Ehlers, M.R., Fox, E.A., Strydom, D.J., \& Riordan, J.F. (1989). Molecular cloning of human testicular angiotensin-converting enzyme: the htestis isozyme is identical to the Cterminal half of endothelial angiotensinconverting enzyme. Proceedings of the National Academy of Sciences, 86(20), 7741-7745.

El Ashry el, S.H., Amer, M.R., Abdalla, O.M., Aly, A.A., Soomro, S., Jabeen, A., ... Ul-Haq, Z. (2012). Synthesis, biological evolution, and molecular docking studies of benzyl, alkyl and glycosyl [2-(arylamino)-4,4-dimethyl-6oxo-cyclohex-1-ene]carbodithioates, as potential immunomodulatory and immunosuppressive agents. Bioorganic \& Medicinal Chemistry, 20(9), 3000-3008. doi:10.1016/j.bmc.2012.03.003

Ferranti, P., Traisci, M.V., Picariello, G., Nasi, A., Boschi, V., Siervo, M., ... Addeo, F. (2004). Casein proteolysis in human milk: tracing the pattern of casein breakdown and the formation of potential bioactive peptides. Journal of Dairy Research, 71(1), 74-87. doi:10.1017/S0022029903006599

FitzGerald, R.J., Murray, B.A., \& Walsh, D.J. (2004). Hypotensive peptides from milk proteins. The Journal of Nutrition, 134(4), 980S$988 \mathrm{~S}$.

Gasteiger, E., Hoogland, C., Gattiker, A., Duvaud, S., Wilkins, M.R., Appel, R.D., \& Bairoch, A. (2005). Protein identification and analysis tools on the ExPASy Server. In The Proteomics Protocols Handbook. Humana Press. Retrieved from http://web.expasy.org/tagident/tagidentdoc.html
Geerlings, A., Villar, I.C., Zarco, F.H., Sanchez, M., Vera, R., Gomez, A.Z., ... Duarte, J. (2006). Identification and characterization of novel angiostensin-converting enzyme inhibitors obtained from goat milk. Journal of Dairy Science, $\quad 89(9), \quad 3326-2225$. doi:10.3168/jds.S0022-0302(06)72369-4

Grosclaude, F., Mercier, J.C., \& Ribadeau-Dumas, B. (1970). Primary structure of bovine alpha S1 casein. Amino acid sequence of the $\mathrm{NH}_{2}$-terminal portion. European Journal of Biochemistry, 16(3), 447-452.

Kitchen, D.B., Decornez, H., Furr, J.R., \& Bajorath, J. (2004). Docking and scoring in virtual screening for drug discovery: methods and applications. Nature Reviews Drug Discovery, 3(11), 935-949. doi:10.1038/nrd1549

Korhonen, H., \& Pihlanto, A. (2006). Bioactive peptides: production and functionality. International Dairy Journal, 16(9), 945-960. doi:10.1016/j.idairyj.2005.10.012

Lagonigro, R., Pietrola, E., D'Andrea, M., Veltri, C., \& Pilla, F. (2001). Molecular genetic characterization of the goat S2-casein $E$ allele. Animal Genetics, 32(6), 391-393. doi:10.1046/j.1365-2052.2001.0781c.x

Lee, J.K., Kim, S.B., Ryu, J.S., Shin, H.S., \& Lim, J.W. (2005). Separation and purification of angiostensin converting enzyme inhibitory peptides derived from goat's milk casein hydrolysates. Asian-Australasian Journal of Animal Sciences, 18(5), 741-746. doi:10.5713/ajas.2005.741

Li, P., Jia, J., Fang, M., Zhang, L., Guo, M., Xie, J., ... Wei, D. (2014). In vitro and in vivo ACE inhibitory of pistachio hydrolysates and in silico mechanism of identified peptide binding with ACE. Process Biochemistry, 49(5), 898-904. doi:10.1016/j.procbio.2014.02.007

Li-Chan, E. C. (2015). Bioactive peptides and protein hydrolysates: research trends and challenges for application as nutraceuticals and functional food ingredients. Current Opinion in Food Science, 1, 28-37. doi:10.1016/j.cofs.2014.09.005

Lipinski, C., \& Hopkins, A. (2004). Navigating chemical space for biology and medicine. Nature, 432(7019), 855-861. doi:10.1038/nature03193 
Lopez-Fandino, R., Otte, J., \& van Camp, J. (2006). Physiological, chemical and technological aspects of milk-protein-derived peptides with anihypertensive and ACE-inhibitory activity. International Dairy Journal, 16(11), 1277-1293. doi:10.1016/j.idairyj.2006.06.004

Maeno, M., Yamamoto, N., \& Takano, T. (1996). Identification of an antihypertensive peptide from casein hydrolysate produced by a proteinase from Lactobacillus helveticus CP790. Journal of Dairy Science, 79(8), 1316-1321. doi:10.3168/jds.S00220302(96)76487-1

Nakamura, Y., Yamamoto, N., Sakai, K., Okubo, A., Yamazaki, S., \& Takano, T. (1995). Purification and characterization of angiotensin I-converting enzyme inhibitors from sour milk. Journal of Dairy Science, 78(4), 777-783. doi:10.3168/jds.S00220302(95)76689-9

Natesh, R., Schwager, S.L., Sturrock, E.D., \& Acharya, K.R. (2003). Crystal structure of the human angiotensin-converting enzyme lisinopril complex. Nature, 421(6922), 551554. doi:10.1038/nature01370

Parmley, W. (1998). Evolution of angiotensinconverting enzyme inhibition in hypertension, heart failure, and vascular protection. American Journal of Medicine, 105(1A), 27S-31S.

Pierri, C.L., Parisi, G., \& Porcelli, V. (2010). Computational approaches for protein function prediction: a combined strategy from multiple sequence alignment to molecular docking-based virtual screening. Biochimica et Biophysica Acta (BBA) Proteins and Proteomics, 1804(9), 16951712. doi:10.1016/j.bbapap.2010.04.008
Pihlanto-Leppala, A., Koskinen, P., Piilola, K., Tupasela, T., \& Korhonen, H. (2000). Angiotensin I-coverting enzyme inhibitory properties of whey protein digests: concentration and characterization of active peptides. Journal of Dairy Research, 67(1), 53-64.

Roy, P.P., Paul, S., Mitra, I., \& Roy, K. (2009). On two novel parameters for validation of predictive QSAR models. Molecules, 14(5), 1660-1701. doi:10.3390/molecules 14051660

Vermeirssen, V., van der Bent, A., van Camp, J., van Amerongen, A., \& Verstraete, W. (2004). A quantitative in silico analysis calculates the angiotensin I converting enzyme (ACE) inhibitory activity in pea and whey protein digests. Biochimie, 86(3), 231-239. doi:10.1016/j.biochi.2004.01.003

Wang, Z.L., Zhang, S.S., Wang, W., Feng, F.Q., \& Shan, W.G. (2011). A novel angiotensin I converting enzyme enzyme inhibitory peptide from the milk casein: virtual screening and docking studies. Agricultural Sciences in China, 10(3), 463-467. doi:10.1016/S1671-2927(11)60026-6

Yamamoto, N., Akino, A., \& Takano, T. (1994). Antihypertensive effect of the peptides derived from casein by an extracellular proteinase from Lactobacillus helveticus CP790. Journal of Dairy Science, 917-922. doi:10.3168/jds.S0022-0302(94)77026-0 